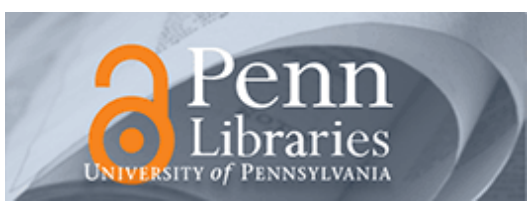

University of Pennsylvania ScholarlyCommons

1975

\title{
The Origins of the Female-Headed Black Family: The Impact of the Urban Experience
}

Frank F. Furstenberg

University of Pennsylvania, fff@ssc.upenn.edu

Theodore Hershberg

John Modell

Follow this and additional works at: http://repository.upenn.edu/sociology_papers

Part of the Family, Life Course, and Society Commons, and the Urban Studies and Planning Commons

\section{Recommended Citation}

Furstenberg, Frank, Theodore Hershberg, and John Modell. 1975. "The Origins of the Female-Headed Black Family: The Impact of the Urban Experience." Journal of Interdisciplinary History 6 (2): 211-233. http:// dx.doi.org/10.2307/202232

This paper is posted at ScholarlyCommons. http://repository.upenn.edu/sociology_papers/3

For more information, please contact repository@pobox.upenn.edu. 


\title{
The Origins of the Female-Headed Black Family: The Impact of the Urban Experience
}

\author{
Disciplines \\ Family, Life Course, and Society | Sociology | Urban Studies and Planning
}


Frank F. Furstenberg, Jr.,

Theodore Hershberg, and John Modell

\section{The Origins of the \\ Female-Headed Black Family: \\ The Impact of the Urban Experience}

The link between

family structure and social mobility has been a topic of considerable sociological speculation. For some years now, there has been a running controversy among scholars working in the area of the family as to whether certain kinship arrangements are especially conducive to success in an industrial society. Specifically, a general proposition was set forth, principally by Parsons, that the most prevalent family form in this society-the nuclear household-emerged at about the time of industrialization in response to demands of the economy for a highly flexible, mobile, emotionally bonded, small kin unit. Parsons contends that extended family forms restrict social mobility by subordinating immediate economic motives to longer range familial interests. Strong commitment to kin, according to this line of reasoning, detracts from unqualified commitment to economic achievement, for it fosters a sense of collectivity rather than individualism, an emphasis on personal qualities rather than on general performance. ${ }^{I}$

Frank F. Furstenberg, Jr., is Associate Professor of Sociology at the University of Pennsylvania. Theodore Hershberg is Associate Professor of History at the University of Pennsylvania. John Modell is Associate Professor of History at the University of Minnesota.

The authors wish to express their appreciation to the Center for the Study of Metropolitan Problems, National Institute of Mental Health, the financial support of which (MHi662I) has made this research possible. An earlier version of this paper was presented at the 1973 annual meeting of the American Sociological Association.

The data presented here were collected by the Philadelphia Social History Project, directed by Theodore Hershberg. They are part of a larger study of the impact of urbanization, industrialization, and immigration on social and family structure, the formation and transformation of neighborhoods, the organization of and journey to work, the development of an intra-urban transportation network, and patterns of migration and social mobility. To study these topics, a massive machine-readable data base has been created describing individual persons, families, businesses, manufacturing firms, and transportation facilities. See Theodore Hershberg, "The Philadelphia Social History Project: A Methodological History,” unpub. Ph.D. diss. (Stanford, 1973). The authors are indebted to the critical readings of Etienne van de Walle and John Durand.

I Talcott Parsons, "Age and Sex in the Structure of the United States," American Sociological Review, VII (I942), 604-6I6; Parsons and Robert F. Bales, Family, Socialization and the Interaction Process (New York, 1965), ch I. 
Although the functional explanation for the family in contemporary Western society has a plausible ring, empirical support has been conspicuously absent. Indeed, many of the studies on the relationship of the economy, family forms, and social mobility have failed to confirm even basic assumptions underlying the evolution of the contemporary Western family: (I) several historical studies have cast doubt on the proposition that the traditional family in Western society was extended and non-nuclear in form in preindustrial society; (2) crosscultural comparisons suggest that although the form of the family is changing in many societies in response to economic conditions, various family forms can co-exist with industrialized economies; (3) relations with extended kin abound in contemporary society, indicating that the family is not so nuclear or isolated as was supposed in the classic formulation; (4) extensive kinship relations may promote social mobility by providing economic resources and social support not available in a small family unit. ${ }^{2}$

The evidence which runs counter to the classic formulation of the functional relationship between industrialization and social mobility is still inconclusive; nevertheless, it suggests that it is a sociological problem that bears further consideration. Until further historical data are assembled, there is little basis to select among the conflicting interpretations or to develop a more integrative theory.

In recent years, however, another even more compelling reason for gathering further information on this problem has arisen. As attention shifted in the I960s from an undifferentiated examination of the experience of the "American family" to a more detailed inspection of the subcultural variations in family form, a bitter debate erupted on one aspect of the broad question of the articulation of economy, family, and social mobility. At the locus of this disagreement was the question of whether "structural defects" in the black family accounted for the economically disadvantaged position of blacks in American society.

2 Ethel Shanas and Gordon F. Streib (eds.), Social Structure and the Family: Generational Relations (Englewood Cliffs, N.J., I965); Marvin B. Sussman, "The Isolated Nuclear Family: Fact or Fiction ?" Social Problems, VI (1959), 333-340; Sussman and Lee Burchinal, "Kin Family Network: Unheralded Structure in Current Conceptualizations of Family Functioning," Marriage and Family Living, XXIV (1962), 22I-240; Eugene Litwack, "Occupational Mobility and Extended Family Cohesion," American Sociological Review, XXV (1960), 9-2I ; Elizabeth Bott, Family and Social Network (London, 1957); William J. Goode, World Revolution and Family Patterns (New York, 1963). See also Michael Gordon and Tamara K. Hareven (eds.), "New Social History of the Family," special issue of Journal of Marriage and the Family, XXXV (1973). 
Even before and especially since the earlier writings of Frazier, the sociological writings on the black family were heavily laced with references to the destructive legacy of slavery, the missing male, and the matrifocal character of black family life. ${ }^{3}$ However, Frazier's observations were amplified and extended in the early 1960s in Nathan Glazer and Daniel P. Moynihan's widely acclaimed book, Beyond the Melting Pot (Cambridge, Mass., 1964). While acknowledging the impact of prejudice and economic discrimination, Glazer and Moynihan, following Frazier, traced the current position of blacks in America back to slavery. They contended that the black family, weakened by slavery, could not withstand the pressures of urban life.

In reviewing the Glazer/Moynihan section on the condition of the black family in the nineteenth century, it is impossible not to be impressed by the absence of supporting data. Both the propositions that slavery resulted in a permanent deterioration of the black family structure and that family structure accounts for economic disadvantage are accepted uncritically. Several years later, the Glazer/Moynihan thesis was restated in the report on the black family that Moynihan prepared for the Johnson administration. In this later document, the argument is further amplified and family structure is accorded even greater importance in accounting for the current fate of black Americans:

Obviously, not every instance of social pathology afflicting the Negro community can be traced to the weakness of family structure. . . . Nonetheless, at the center of the tangle of pathology is the weakness of the family structure.... It was by destroying the Negro family under slavery that white Americans broke the will of the Negro people. Although that will has reasserted itself in our time, it is a resurgence doomed to frustration unless the viability of the Negro family is restored.4

Needless to say, the Moynihan report has engendered a heated discussion of a number of crucial issues: What was the impact of slavery on the family structure of Afro-Americans? How does family structure shape prospects of economic success in American society? How do the answers to these questions contribute to our understanding of the potential effect of various strategies for ameliorating economic disadvantage? In a very real sense, these questions raised by the Moynihan

3 E. Franklin Frazier, The Negro Family in the United States (Chicago, 1939).

4 Lee Rainwater and William Yancey (eds.), The Moynihan Report and the Politics of Controversy (Cambridge, Mass., I967), 76. 
thesis are specifications of the general problem of how family structure is linked to economic success in American society. Are certain forms of the family more or less conducive to social mobility in an industrialized economy? Specifically, is there reason to believe that the couple-headed nuclear family is better equipped to utilize economic resources and confer special advantages on their offspring than a noncouple-headed or non-nuclear family structure?

A few contemporary studies have explored the link between family structure and social mobility with largely inconclusive results. ${ }^{5}$ The most penetrating historical studies have so far concentrated on questioning the link between slavery and black family structure. ${ }^{6}$ As yet, little historical information has been brought to bear on the status of the black family relative to other ethnic groups and the economic consequences of family structure for people of different ethnic backgrounds. Thus, it is not even known whether sizable variations existed in the structure of families among various ethnic groups prior to this century, much less whether such variations influenced the mobility patterns of these different populations.

This paper examines how family structure and family composition varied by ethnic group in the second half of the nineteenth century in Philadelphia, the nation's second largest city. Our analysis is based on samples drawn from the decennial Federal population manuscript schedules for 1850 through I 880 . The black sample consists of all black households; the white ethnic samples are drawn systematically from the whole number of households headed by immigrants from Ireland and Germany, and by native white Americans. None includes fewer than 2,000 households for each census year. ${ }^{7}$

THE STRUCTURE OF THE HOUSEHOLD Although our information does not reach back into the early nineteenth century, it does lend

5 O. D. Duncan and Beverly Duncan, "Family Stability and Occupational Success," Social Problems, XVI (1969), 273-285.

6 Herbert Gutman, "Persistent Myths about the Afro-American Family," above, I8I-2 Io. See also Theodore Hershberg, "Free Blacks in Antebellum Philadelphia: A Study of Ex-slaves, Freeborn and Socioeconomic Decline," Journal of Social History, V (I97I), I 83-209; Elizabeth Pleck, "The Two-Parent Household: Black Family Structure in Late Nineteenth-Century Boston," Ibid. VI (1972), 3-3I.

7 About 4 percent of the city's population were neither black, Irish, German, nor native white. For a detailed description of how the samples were drawn, see Hershberg, "Philadelphia Social History Project," ch. 2. 
further support to the position that complex households were less common than simple nuclear structures, at least in one major urban area. ${ }^{8}$ When we examined the 1880 data from Philadelphia, several interesting observations came to light. First, considering only those families in which a child was present, more than three-fourths of the households in Philadelphia consisted of nuclear families, that is families comprised of parents and children with no other relatives present in the home. Of greatest significance is our finding that only minor variations exist among the four ethnic groups (Table I). Blacks and native whites were slightly less likely to reside in nuclear households than the Irish and German, probably in large measure because the latter groups - more recent immigrants to Philadelphia—had less time for extended kin to develop in this country.

Table 1 Household Structure by Ethnicity, $1880^{a}$

\begin{tabular}{lcccc}
\hline & BLACK & IRISH & GERMAN & NWA \\
Nuclear & $75.2 \%$ & $82.2 \%$ & $84.5 \%$ & $73 . \mathrm{I} \%$ \\
Extended & $\mathrm{I} 7.3$ & I0.6 & I0.2 & I7.0 \\
Expanded & 7.5 & 7.3 & 5.3 & 9.9 \\
& $N=2,949$ & $N=\mathrm{I}, 637$ & $N=\mathrm{I}, 766$ & $N=\mathrm{I}, 730$
\end{tabular}

a The figures in this and the following tables refer only to households with children. Here and throughout tables, decimals in total percentage are due to rounding.

Extended families were the second most common household arrangement. Approximately I4 percent of the sample resided in threegeneration families, a figure somewhat greater than the proportion in the current census of Philadelphia. Again we find little variation among the different ethnic groups in the proportion of extended households. Blacks had the highest proportion (I7.3 percent); the lowest were German immigrants, of whom 10.2 percent were residing in threegeneration families. Expanded families made up only 7 percent of the households. Again, no conspicuous differences appear among ethnic

8 For purposes of this analysis, a detailed code of family forms was developed. Families are classified into nuclear, extended (households of three or more generations), and expanded (households with additional relatives but which do not extend generationally). These family types are further subdivided into couple-headed, male-headed, and femaleheaded. This distinction allows us to look at the family composition within the three different structural forms. For each of these nine types, a further breakdown is made between those families with and without children. 
groups. In particular, blacks were about as likely as other ethnic groups to be organized in complex households, and the patterns between the blacks and native white Americans are almost identical. Thus, whatever the benefits or liabilities of the nuclear family in promoting economic mobility, the household structure cannot explain the differential patterns of social mobility which emerge in the latter part of the nineteenth century.

CHANGES IN HOUSEHOLD STRUCTURE OVER TIME Of course, it is possible that, by I880, many changes had already taken place in the structure of the family, that our snapshot was taken after the action occurred. In particular, one might speculate that it was too late to detect the damage done to the black family by slavery. Even if this were the case, it would represent a finding of great worth, suggesting that the presumed effects of slavery were quickly erased and that the structure of the contemporary black family could hardly be traced in an unbroken line back to slavery. Our evidence, however, casts doubt even on this hypothesis. When the household composition of the black family in I 880 is compared with the structure of the black household in the antebellum period in 1850 , we discover a remarkable degree of continuity. Virtually the same proportion of blacks were living in nuclear households in I850 as in I880. Indeed, if anything, there had been a slight decrease in nuclear households.

Other ethnic groups revealed a slight trend toward nuclearity; however, the increase in each case was only a few percentage points (Table 2). A part from the information that these figures provide about the black family, the comparisons of household structure over time are significant in another respect. They offer little support for the proposition that household structure was changing, at least within the urban areas, as a result of increasing industrialization. This finding, again, seems to run counter to the widely held view that the American family evolved from an extended family to a nuclear family in response to changing industrial conditions. Of course, the findings here are limited, not only in time, but, more significantly, to an urban population. Quite possibly the impact of industrialization on family structure was accomplished by migration from rural America to the rapidly growing cities.

Our data do not permit a direct test of the effects of industrialization on the family. In subsequent analyses, however, we shall be able to examine the link between the occupational and family structure within the city of Philadelphia during the middle and latter part of the 
Table 2 Household Structure by Ethnicity, I850 and I880

\begin{tabular}{lcccc}
\hline \multicolumn{5}{c}{ INFERRED RELATIONSHIPS, I $850^{\mathrm{a}}$} \\
Nuclear & BLACK & IRISH & GERMAN & NWA \\
Extended & $60.6 \%$ & $60.6 \%$ & $61.4 \%$ & $45.6 \%$ \\
Expanded & 6.6 & 4.4 & 3.5 & 4.7 \\
& 32.8 & 35.0 & 35.0 & 49.7 \\
& $N=\mathrm{I}, 739$ & $N=\mathrm{I}, 844$ & $N=\mathrm{I}, 564$ & $N=\mathrm{I}, 648$ \\
& INFERRED RELATIONSHIPS, I880 & \\
Nuclear & BLACK & IRISH & GERMAN & NWA \\
Extended & $57.6 \%$ & $67 . \mathrm{I} \%$ & $65.5 \%$ & $52.4 \%$ \\
Expanded & 4.9 & 5.6 & 4.3 & 5.3 \\
& 37.6 & 27.2 & 30.2 & 42.3 \\
& $N=3,206$ & $N=\mathrm{I}, 637$ & $N=\mathrm{I}, 726$ & $N=\mathrm{I}, 680$
\end{tabular}

a The Federal population manuscript schedules of the United States Census became for the first time in I850 an enumeration of every inhabitant of the nation, and recorded important information describing each individual within each household unit; but it was not until I 880 that the relationship of each member of the household to the household head was recorded. Researchers using the schedules for I 850, I 860, and I870, therefore, must infer these relationships from the information which was included, such as surname, age, sex, position of listing in the household, etc. The PSHP has developed a computer program to make these inferences; see Theodore Hershberg, "A Method for the Computerized Study of Family and Household Structure Using the Manuscript Schedules of the U.S. Census of Population, I850-1880," The Family in Historical Perspective, An International Newsletter, I (1973), 6-20; Buffington Clay Miller, "A Computerized Method of Determining Family Structure from Mid-Nineteenth Century Census Data," unpub. M.S. diss. (Moore School of Electrical Engineering, University of Pennsylvania, I972). For the analysis of the I 880 data presented in this paper, however, we have used the given relationships, as recorded in the 1880 manuscript census. In the I 850 and I880 "inferred" tables, individual relationships which cannot be determined by the computer program (such as "Servant," "Brother-in-Law") are categorized as "Others." The computer program assigns households with "Others" to the expanded category (households with relatives), thus considering all "Others" as relatives. The expanded category, therefore, is inflated by the number of households with only non-relative "Others" (boarders and servants). This can be seen by comparing Table 2 for 1880 based on "inferred" relationships with Table I based on "given" relationships.

nineteenth century. Although not definitive, this forthcoming analysis should provide some clue to the effect of industrialization on the American family in urban areas of the country.

ETHNICITY AND FAMILY COMPOSITION Earlier we drew a distinction between household structure and family composition (referring to the membership of the family unit). Most contemporary research on 
the black family has been concerned, not with the issue of household structure, but with that of family membership. In particular, researchers have been preoccupied with the question of who heads the family unit. As we noted earlier, there is reason to wonder whether this question deserves the prominence that it has received. Reserving our judgment on this issue, we shall in this section examine whether the family composition of blacks differs significantly from other ethnic groups before the turn of the century.

Households were divided into three categories: couple-headed households in which a male was head and in which his wife was listed as present in the home; male-headed households in which the wife was not listed as present in the home; female-headed households. This basic division does not take into account whether the households were nuclear or some complex unit. Furthermore, we again considered only those households in which children were present. ${ }^{9}$

Using this simple classification scheme, there is a noticeable relationship between family composition and ethnicity in the 1850 and 1880 census data (Table 3). German Americans are most likely to be living in couple-headed households, followed by native whites, closely in I880 but less so in 1850 . Irish households were somewhat less likely to be couple-headed and blacks had the lowest proportion of families in which both parents were present. Thus, the contemporary pattern of a high prevalence of matrifocal households among blacks is visible before the turn of the century and before the arrival in the city of numbers of freedmen.

It is one thing to demonstrate the existence of this pattern and quite another to interpret its significance. In the first place, the magnitude of

9 In two recent studies on black family structure (Gutman, "Persistent Myths"; Pleck, "Two-Parent Household"), the proportion of female-headed households is misrepresented because the calculations include couple-headed households without children. We disagree with this procedure for three reasons. First, to include childless couples but not households with a single member biases the proportion of female heads substantially downward. Second, the assumption that underlies the association of the female-headed household with a set of negative social consequences is that the absence of a father adversely affects the socialization of the young. To include childless families, therefore, introduces an irrelevant component. Third, this irrelevant component has a downward bias because childless families tend to be younger and less likely to have experienced family dissolution. A further refinement might have been to remove from consideration those families where the youngest child in the household was presumably beyond the age of childhood socialization. Among the 1880 blacks, applying age 20 as the cutoff point would have removed almost is percent of the families from consideration. Such a procedure, however, would have affected almost exclusively the oldest categories of families, and would leave untouched the distinctions and trends treated in this paper. 
Table 3 Family Composition by Ethnicity, I 850 and I880

\begin{tabular}{lcccc}
\hline \multicolumn{5}{c}{ INFERRED HEADSHIP, I850 } \\
& BLACK & IRISH & GERMAN & NWA \\
Female Head & $22.5 \%$ & I3.4\% & $3.3 \%$ & I3.3\% \\
Male Head & 6.0 & 7.2 & 3.2 & 4.0 \\
Couple Head & $7 \mathrm{I} .5$ & 79.4 & 93.5 & 82.6 \\
& $N=\mathrm{I}, 739$ & $N=\mathrm{I}, 844$ & $N=\mathrm{I}, 564$ & $N=\mathrm{I}, 648$ \\
& \multicolumn{5}{c}{ GIVEN HEADSHIP, I 880} & \\
Female Head & $25.3 \%$ & I2.7\% & $8.3 \%$ & I3.6\% \\
Male Head & 5.9 & 7.5 & 5.3 & 6.2 \\
Couple Head & 68.8 & 79.8 & 86.5 & 80.2 \\
& $N=2,949$ & $N=\mathrm{I}, 637$ & $N=\mathrm{I}, 766$ & $N=\mathrm{I}, 730$
\end{tabular}

a Although inferring household structure by computer is difficult, inferring household headship is simple and certain. Results derived by such an inference are almost exactly those found from "given" relationships. Were we to use "inferred" figures for headship in I880, the percentage of female heads would be 24.5, I2.6, 8.5, and II. 5 for the blacks, Irish, Germans, and native whites, respectively.

the difference can be seen in two quite separate lights. We could say that blacks are more than twice as likely as foreign and native-born white Americans to live in households headed by a female. Such a statement emphasizes the differential. Alternatively, we could point out that the great majority of all ethnic groups live in couple-headed households. Even among blacks, only one-fourth of the households were headed by a female. Moreover, among the various ethnic groups there is a difference of only I7 percentage points between the group with the lowest proportion of female-headed households-the German Americans-and that with the highest, black Americans. Obviously, this characterization tends to minimize the differences by underscoring the similarities. The only reasonable way of resolving this issue of interpretation is to delve further into the source of these differences. To us, their significance is to be found more in how they came about than in their magnitude.

Contemporary research on female-headed families has demonstrated the existence of a strong link between economic status and family composition. Male absence is far more prevalent in the lower class than in the middle class. Accordingly, differences in female-headedness between blacks and whites diminish sharply under conditions of economic parity. This finding has caused many to question the position that variations in family composition can be traced to divergent subcultural 
standards. In many respects the argument that the roots of the black matrifocal family are to be found in slavery represents an extension of the subcultural argument, and the same criticisms that pertain to the subcultural explanation can be applied historically.

New historical studies provide compelling reason to question the destructive impact which slavery allegedly had on the black family. One of the major conclusions reached by econometric historians Fogel and Engerman is that the slave family was considerably stronger than has been believed. Further evidence which challenges the standing interpretation comes from research conducted by Gutman, whose data are consistent with conclusions reached by Fogel and Engerman. In groundbreaking essays, Gutman examined "the family patterns of those Negroes closest in time to actual chattel slavery," and did not find "instability," "chaos," or "disorder." Instead, in fourteen varied Southern cities and counties between I865 and I880, Gutman found viable two-parent households ranging from 70 to 90 percent. The empirical picture presented here is staggering. Gutman's data make clear that the vast majority of black families were headed by both parents, and they convincingly contradict the view that slavery "destroyed" the black family. ${ }^{10}$

The data for Philadelphia, moreover, are consistent with the findings of Gutman, and Fogel and Engerman. We know from unique information on status-at-birth reported in a Quaker census of Philadelphia blacks in I 847 that only ro percent of all of the city blacks had been born slaves. More importantly, however, these ex-slaves were more likely than than the freeborn to have two-parent households. However unrepresentative of all slaves the ex-slaves in Philadelphia's population may have been, direct contact with slavery cannot explain the degree of matrifocality which existed at mid-century. II In I 880, one out of every two Philadelphia blacks had been born in the South. Although it is impossible to know with absolute certainty who among these immigrants had been freeborn or slaveborn, place of birth constitutes a plausible proxy for exslave status, especially when considered in conjunction with illiteracy. ${ }^{12}$

Io Robert William Fogel and Stanley L. Engerman, Time on the Cross: The Economics of American Negro Slavery (Boston, I974), I, 5, I26-I44; Gutman, "Persistent Myths." II Hershberg, "Free Blacks," I92-204.

I2 See Pleck, "Two-Parent Household," I8-I9; note 3, above. Although there are problems in this approach, combining the variables of place of birth and illiteracy brings us closer to identifying accurately those blacks most likely to have been slave-born. There were slightly more female illiterates among both northern-born and southern-born black Philadelphians, but this difference was not at all of a magnitude to suggest that the relationships shown in Table 4 are spurious. 
Therefore, if the slavery argument is valid, this segment of the population should account for a disproportionate share of the female-headed households. Yet this, in fact, was not the case: southern-born illiterate blacks were less likely than their northern-born counterparts to have femaleheaded families (Table 4 ).

Table 4 Black Family Composition by Literacy and Place of Birth, $\mathrm{I}_{880^{a}}$

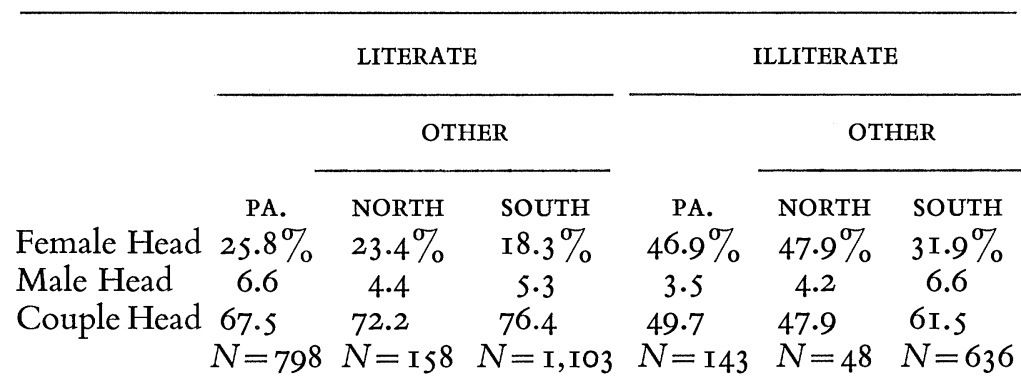

a Literacy and place of birth refer to the household head.

FAMILY COMPOSITION AND ECONOMIC CONDITION In place of the subcultural "legacy of slavery" explanation for disorganization in the black family, we wish to argue for the primacy of urban economic and demographic factors. The vast majority of Philadelphia's blacks faced a life of abject poverty. Job discrimination was ubiquitous in the economy. Of every ten black males in the labor force, eight worked at unskilled jobs; the comparable figure for the Irish was five, and for the Germans and native whites fewer than two (see Table 5). When converted to wages and yearly income, these figures bear stark testimony to the difficulty black men faced in attempting to raise and provide for their families. Although there is some disagreement over the amount of a subsistence income for families in $\mathrm{I} 88 \mathrm{O}$, it is quite clear that unskilled laborers were faced with a serious shortfall. ${ }^{13}$ In such grim economic

I3 Eudice Glassberg calculates the subsistence income for a family of five in "Philadelphia's Poverty Line, I860 and I880: A Comparison of Earnings and Minimum Standard of Living," unpub. paper, PSHP (Oct. I973). Unskilled workers rarely made as much as $\$ 400$ a year. Using Glassberg's figures, the shortfall is about 40 percent. Most families were able to compensate in a variety of ways, which included working wives and children, the pooling of income in expanded and extended families, the taking in of boarders, etc. 
Table 5 Occupational Structure by Ethnicity, I880

\begin{tabular}{|c|c|c|c|c|}
\hline & (FOR MALE & I 8 YEARS A & OLDER) & \\
\hline $\begin{array}{l}\text { Professional High } \\
\text { White Collar }\end{array}$ & $\begin{array}{r}\text { BLACK } \\
\text { I.I \% }\end{array}$ & $\begin{array}{l}\text { IRISH } \\
\text { I. } 6 \%\end{array}$ & $\begin{array}{c}\text { GERMAN } \\
\text { I. } 6 \%\end{array}$ & $\begin{array}{l}\text { NWA } \\
5.1 \%\end{array}$ \\
\hline $\begin{array}{l}\text { Proprietary }{ }^{\text {a Low }} \\
\text { White Collar }\end{array}$ & $4 \cdot 4$ & I3.4 & I7.5 & 27.8 \\
\hline Skilled & I 3.7 & $3 \mathrm{I} .5$ & 59.7 & $45 \cdot 3$ \\
\hline Unskilled & $\begin{array}{c}79.2 \\
N=8,700\end{array}$ & $\begin{array}{c}\text { SO.I } \\
N=36,333\end{array}$ & $\begin{array}{c}\text { I } 5.3 \\
N=25, \text { I72 }\end{array}$ & $\begin{array}{c}\text { I7.2 } \\
N=90,756\end{array}$ \\
\hline
\end{tabular}

a Percentages do not add up to Ioo; the missing percentages-I.6, 3.5, 5.9, and 4.6-for the four groups, respectively, represent a category of ambiguous occupational designation such as "liquor store." Based on other characteristics of this category, we suspect that such individuals were in fact proprietors and should be added to the "proprietary" category.

circumstances, the conditions for the maintenance of stable family life were at best precarious.

These economic circumstances bear a direct and powerful relationship to the incidence of female-headed families. This can be seen in Table $6 \mathrm{~A}$, which relates wealth (real and personal property holdings) to family composition. Wealth data are not reported in the manuscript schedules for 1880 , but they are for 1870 . In that year, as in 1880 , a greater percentage of black families with children were headed by females (27.I) than for the Irish (I6.9), Germans (5.9), and native whites (I4.3). Female-headedness varies inversely with wealth. They were found far less often among families with property valued at more than $\$ 500$ than among propertyless families: half as often for the blacks and Irish; two-thirds as often for the native whites; and one-third as often for the Germans. Table $6 \mathrm{~B}$ focuses on a special group of household heads, those $30-39$ years of age. By examining this group, we eliminate variations which arise from different age structures among the four ethnic groups-an important control because age structure is strongly related both to mortality and to the acquisition of wealth. The same inverse relationship between femaleheadedness and wealth is found in the 30-39 age group, but the strength of the relationship is far more pronounced.

Table 7 presents these same data in a different form, as the percent differences in female-headedness between blacks and each of the three white groups. Using different wealth categories Table 7 B shows that the original variation observed between all black and Irish families with 
Table 6 Proportion of Household Heads Female, by Ethnicity and Wealth, $1870^{\mathrm{a}}$

\begin{tabular}{|c|c|c|c|c|c|c|c|}
\hline $\begin{array}{l}\text { WEALTH } \\
\$\end{array}$ & BLACK & & ISH & GEF & MAN & & WA \\
\hline 0 & $3 \mathrm{I} .2(\mathrm{I}, 4 \mathrm{I} 4)$ & $2 \mathrm{I} \cdot 3$ & $(889)$ & 9.6 & (6I6) & I8.8 & (674) \\
\hline 100-199 & 20.2 (I29) & I 5.9 & $(\mathrm{I} I 3)$ & 8.3 & (96) & I6.7 & (96) \\
\hline $200-299$ & I8.7 & 12.9 & (IOI) & 4.5 & (I32) & 8.3 & (I57) \\
\hline $300-499$ & I 4.6 & 10.7 & $(75)$ & 3.2 & $(156)$ & I0.6 & (I79) \\
\hline 500-999 & $8.3 \quad(72)$ & $9 \cdot 3$ & $(75)$ & $3 \cdot 7$ & (I89) & 10.5 & (I43) \\
\hline $1,000+$ & I7.0 (206) & 10.6 & $(378)$ & 3.5 & (633) & I2.8 & (695) \\
\hline All & 27. I (I,962) & I6.9 & $1,636)$ & 5.9 & $1,825)$ & I 4.3 & $I, 946)$ \\
\hline
\end{tabular}

B. HOUSEHOLDS WITH CHILDREN HEADED BY 30-39 YEAR OLDS

\begin{tabular}{lrrrrrrrr}
\multicolumn{1}{c}{ O } & 25.8 & $(395)$ & I8.I & $(282)$ & $6 . \mathrm{I}$ & $(2 \mathrm{I} 2)$ & I4.2 & $(2 \mathrm{II})$ \\
IOO-I99 & II.I & $(36)$ & 5.7 & $(35)$ & 5.4 & $(37)$ & $9 . \mathrm{I}$ & $(33)$ \\
$200-299$ & 8.0 & $(25)$ & 7.9 & $(38)$ & 0 & $(54)$ & 6.9 & $(58)$ \\
$300-499$ & $7 . \mathrm{I}$ & $(\mathrm{I} 4)$ & 4.8 & $(2 \mathrm{I})$ & 0 & $(43)$ & 3.4 & $(58)$ \\
$500-999$ & I5.0 & $(20)$ & \multicolumn{1}{c}{0} & $(22)$ & $\mathrm{I} .5$ & $(65)$ & $8 . \mathrm{I}$ & $(62)$ \\
I,000+ & 6.3 & $(32)$ & 2.3 & $(86)$ & 3.5 & $(\mathrm{I} 72)$ & IO.I & $(\mathrm{I} 78)$ \\
All & $2 \mathrm{I} .8$ & $(522)$ & $\mathrm{I} 2.5$ & $(488)$ & 3.8 & $(583)$ & I0.3 & $(600)$
\end{tabular}

a Wealth consists of all real and personal property holding reported in the census manuscripts. Figures shown are percentages of all households in a particular ethnic wealth category headed by women; the figures in parentheses are the $N s$ for these classes.

children-9.3 percent-is reduced : to 4.5 percent among holders of "any wealth" and yet further to 4.0 percent among holders of "wealth greater than $\$ 1,000$." The same is true for the variation observed between blacks and Germans: the I 8 percent separating them is reduced to 7.0 among holders of "any" wealth and 2.8 percent among holders of "wealth greater than \$I,000." Most striking, however, is the reduction of the variation between blacks and native whites. The observed variation for all families is reduced to I.2 percent among holders of "any" wealth, and for those owning more than $\$ 1,000$ the relationship is reversed: native whites in this category were more likely than blacks to have femaleheaded families. Among the propertied across the entire ethnic spectrum, then, most of the variation in female-headedness is eliminated.

Although the economic data presented in Tables 6 and 7 describe the dramatic reduction of observed variation in female-headedness among holders of property, among the propertyless little or none of the variation is eliminated. There remains, in other words, a variation of II. 5 percent between blacks and native whites, and 9.3 and 18.0 percent 
Table 7 Percentage Difference in Female-Headedness by Property Holdings between Blacks and the White Ethnic Groups, I870

\begin{tabular}{|c|c|c|c|c|}
\hline & $\begin{array}{c}\text { ALL } \\
\text { HOUSEHOLDS }\end{array}$ & $\begin{array}{c}\text { WITHOUT } \\
\text { ANY } \\
\text { WEALTH }\end{array}$ & $\begin{array}{c}\text { WITH } \\
\text { ANY } \\
\text { WEALTH }\end{array}$ & $\begin{array}{c}\text { WITH } \\
\text { WEALTH } \\
\text { GREATER } \\
\text { THAN } \\
\text { \$I,OOO }\end{array}$ \\
\hline \multicolumn{5}{|c|}{ A. ALL HOUSEHOLDS WITH CHILDREN } \\
\hline Black-Irish & I0.2 & 9.9 & 4.8 & 6.4 \\
\hline Black-German & 21.2 & 21.6 & 12.5 & 13.5 \\
\hline Black-Native White & $\mathrm{I} 2.8$ & $\mathrm{I} 2.4$ & $4 \cdot 7$ & 4.2 \\
\hline \multicolumn{5}{|c|}{ B. HOUSEHOLDS WITH CHILDREN HEADED BY 30-39 YEAR OLDS } \\
\hline Black-Irish & 9.3 & 7.7 & 4.5 & 4.0 \\
\hline Black-German & I8.0 & 19.7 & 7.0 & 2.8 \\
\hline Black-Native White & II. 5 & II.6 & 1.2 & -3.8 \\
\hline
\end{tabular}

respectively, between blacks and the Irish and Germans. There are two reasons for this residual variation. The substantial portion is accounted for by differential mortality which we discuss in detail below. The remainder is at least in part an artifact of the way property holding was reported in the Federal population manuscript schedules. Census marshals were instructed not to record property holding in amounts less than \$IOo. When we observe the category "without property," we are in fact looking at two groups: those with some property worth less than $\$ 100$ and those without any property at all. This distinction is an important one to bear in mind. Table 8 displays data describing all black families with children in Philadelphia, collected in 1838 by the Pennsylvania Abolition Society and in 1847 by the Society of Friends. ${ }^{14}$ Unlike the Federal population manuscript schedules, these forms report property holding down to amounts of $\$ 5$, and permit the study of variation in female-headedness along a rank order of wealth which includes 95 percent of all black families.

As with the 1870 Federal census, female-headedness and property holding are negatively related (see Table 8 ). Significantly, this negative relationship is visible for sums of less than $\$ 100$, so that in 1838 , for example, black families with \$50-\$99 of property were only about three-

I4 See Hershberg, "Free Blacks," I84-I 85; idem, "Free-Born and Slave-Born Blacks in Antebellum Philadelphia," in Eugene D. Genovese and Stanley L. Engerman (eds). Race and Slavery in the Western Hemisphere: Quantitative Studies (Princeton, 1975), 395-426. 
Table 8 Proportion of Black Household Heads Female by Wealth, $\mathrm{I} 838$ and $\mathrm{I} 847$

\begin{tabular}{|c|c|c|c|}
\hline \multirow{2}{*}{$\begin{array}{c}\text { WEALTH } \\
\text { FAMILIES WITH }\end{array}$} & \multirow{2}{*}{$\frac{\text { I838 }}{\text { ALL CHILDREN }}$} & \multicolumn{2}{|c|}{ I 847} \\
\hline & & CHILDREN & CHILDREN \\
\hline $0-50$ & $3 \mathrm{I} .4(570)$ & $\begin{array}{c}0-4 \\
27.8(298)\end{array}$ & $\begin{array}{c}5^{-14} \\
37.9(610)\end{array}$ \\
\hline 50-99 & $24.2(24 \mathrm{I})$ & I2.0 (I50) & $22.3(350)$ \\
\hline IOO-499 & I3.3 (420) & 6.I (I8I) & I7.3 (567) \\
\hline $500 \ldots$ & $8.5(216)$ & I6.3 (49) & I0.6 (254) \\
\hline
\end{tabular}

SOURCes: 1838: Manuscript Census, Pennsylvania Abolition Society. I847: Manuscript Census, Society of Friends.

fourths as likely to be female-headed as families with less than $\$ 50$. If, as we have good reason to suppose in light of the occupational distributions of the several groups, whites in the 1870 "less than \$100" category clustered at its higher reaches, while blacks were far more prevalent at the bottom, then an unknown but sizable proportion of the black-white variation among the 1870 "propertyless" can be understood.

FAMILY COMPOSITION AND MORTALITY Differential wealth thus accounts for the observed disparity between Philadelphia's blacks and whites in family composition. Contemporary studies of family life among the poor tend to stress illegitimacy, desertion, and divorce in understanding female headship, but in the nineteenth century a different consideration was the major link between female headship and the poverty cycle: mortality. ${ }^{15}$ Today, family instability can be traced to the limited economic prospects that the poor recognize for themselves; in the last century sickness and death played the more important part. ${ }^{16}$ Those most ravaged were the urban poor blacks, irregularly employed, segregated, and neglected in matters of public health.

Is For evidence of the extraordinary mortality differentials by race (esp. in infant mortality), see the I879 life tables for Baltimore and Washington (which had more blacks than Philadelphia, but similar mortality experiences) in U.S. Census Office, Census of 1880, XII: Mortality and Vital Statistics (Washington, I883), pt. 2, 773-777. See also W. E. B. DuBois' excellent discussion of health and mortality differentials in Philadelphia, in which he lays the blame immediately on the ignorance of hygiene among the victims and on the uneven distribution of public-health effort (The Philadelphia Negro: A Social Study [New York, 1967], ch. 10).

I6 See Frank F. Furstenberg, "Work Experience and Family Life," in James O'Toole (ed.), Work and the Quality of Life (Cambridge, Mass., 1974), 34I-360; Reynolds Farley, Growth of the Black Population (Chicago, 1973). 
Table 9 Reported Marital Status of Female Household Heads, Households with Children, by Ethnicity, I 880

\begin{tabular}{lcccc}
\hline & BLACK & IRISH & GERMAN & NWA \\
Widowed & $74.3 \%$ & $79.5 \%$ & $77.8 \%$ & $75.0 \%$ \\
Single & 5.0 & I.4 & 3.3 & 2.5 \\
Divorced & I.I & 0.9 & 0.7 & I.0 \\
Married & I9.7 & I 8.3 & I 8.3 & $2 \mathrm{I} .5$ \\
& $N=747$ & $N=2$ I9 & $N=$ I 53 & $N=200$ \\
\hline
\end{tabular}

Table 9 seeks to elucidate the contribution of widowhood to femaleheadedness among black families in Philadelphia in I 880 by examining the reported marital status of each female-headed household (for families with children). Though, as we have seen, females constituted a larger minority of all household heads among blacks than in other ethnic groups, Table 9 shows that for blacks as for the others, widowhood overwhelmingly predominates among female household heads. In each ethnic group, most of the remaining female heads are married women whose spouses are absent-presumably deserted in some cases, with husbands temporarily away at work in others. When we combine the separated, divorced, and single mothers, they constitute only one-fourth of all female heads. It is to widowhood, therefore, that we must attribute the excess of female-headedness among black families with children. This stands in stark contrast with today, when among blacks widowhood is overshadowed by separation and single parenthood as a source of family breakup.

Mortality, of course, increases sharply with age. Had the black population been notably older than other groups, their age distribution might account for the prevalence of widowhood. But this is not the case. Table Io presents the composition of families by age, measuring age according to the female's age when she is present, and according to the male's age when she is not. ${ }^{17}$ At every age, the composition of black families is different, with an increasing excess of widows. So fierce was the mortality among Philadelphia's blacks that at least a quarter of the married Negro women in families with children were widowed by their 40s. ${ }^{18}$

I7 The same finding appears when, to avoid the clumsiness of measuring "age" of the family sometimes by the woman, sometimes by the man, we measure it by the age of the oldest child, as a proxy of how long the marriage has been established.

I 8 When all households, and not just those with children, are examined, quite the same white/black pattern of differences obtains. 
Table io, however, goes beyond the obvious and the awful. We note, for instance, that despite the extraordinarily high incidence of widowhood among blacks, widowerhood is rarer among them than in the other groups. This requires explanation. The figures presented are on reported marital status at a given moment in time. Thus, the number of widows counted would (under ideal census conditions) be equal to the

Table 10 Sex and Marital Status of Heads of Households (with Children) by Age of Head and Ethnicity, $1880^{a}$

\begin{tabular}{|c|c|c|c|c|c|}
\hline \multirow{3}{*}{$\begin{array}{l}\text { HEADED BY: } \\
\text { Couples }\end{array}$} & \multicolumn{5}{|c|}{ AGE OF HEAD } \\
\hline & LESS THAN 30 & $30-39$ & $40-49$ & $50-59$ & $60+$ \\
\hline & & & & & \\
\hline Black & 84.5 & 77.2 & 62.0 & 44.8 & 31.0 \\
\hline Irish & 90.7 & 93.5 & 83.5 & 75.5 & 39.5 \\
\hline German & 93.4 & 90.4 & 82.9 & 71.2 & 45.0 \\
\hline NWA & 93.8 & 92.5 & 84.3 & 73.5 & 44.2 \\
\hline \multicolumn{6}{|l|}{ Widows } \\
\hline Black & 4.2 & I I.4 & 20.8 & $29 . \mathrm{I}$ & 35.5 \\
\hline Irish & I.I & 3.2 & 8.6 & 10.3 & I6.8 \\
\hline German & 2.0 & 5.4 & 9.9 & II. 4 & I9.3 \\
\hline NWA & 0.6 & $4 \cdot 4$ & 8.8 & I0.7 & 25.1 \\
\hline \multicolumn{6}{|c|}{ Other Females } \\
\hline Black & 6.7 & 5.3 & $6 . \mathrm{I}$ & 5.7 & 4.7 \\
\hline Irish & 2.3 & I.O & $\mathrm{I} .4$ & I. 8 & 0.8 \\
\hline German & I. 6 & $\mathrm{I} .2$ & 2.7 & 3.2 & 4.2 \\
\hline NWA & 0.9 & $\mathrm{I} .4$ & I. 8 & 2.7 & 2.5 \\
\hline \multicolumn{6}{|l|}{ Widowers } \\
\hline Black & O.I & 0.8 & 2.7 & 4.6 & 12.5 \\
\hline Irish & 0.4 & I. 3 & 3.0 & $7 \cdot 3$ & 26.6 \\
\hline German & 0.4 & I. 3 & I. 3 & 7.1 & 15.8 \\
\hline NWA & 0 & I. 4 & 2.8 & $5 \cdot 3$ & 15.0 \\
\hline \multicolumn{6}{|l|}{ Other Males } \\
\hline Black & 3.9 & 3.6 & 4.2 & 5.0 & 6.0 \\
\hline Irish & 5.2 & I. 7 & I.9 & 5.0 & 4.8 \\
\hline German & 2.7 & I.9 & $2 . \mathrm{I}$ & 3.2 & 5.0 \\
\hline NWA & 4.8 & $\mathrm{I} .2$ & I. 3 & 5.3 & 6.7 \\
\hline \multicolumn{6}{|l|}{$N s$} \\
\hline Black & 899 & 887 & 526 & $28 I$ & I68 \\
\hline Irish & 265 & 418 & 369 & 220 & I 24 \\
\hline German & 256 & 470 & 374 & 253 & 120 \\
\hline NWA & 336 & 517 & 394 & 226 & 120 \\
\hline
\end{tabular}

a Female's age for couples, widows, and other female heads; male's age for widowers and other male heads. Figures shown are percentages. 
number of persons ever widowed, less the number who had remarried; likewise for widowers. Sex differentials in black mortality cannot account for so large a difference. One implication of these statistics is that black men could remarry with relative ease, but black women could not. Another is that a larger proportion of black men than black women who were left with children by the deaths of their spouses found it impossible or inadvisable to raise the children while unmarried, and left them with relatives or others.

Data on marital status by age strongly bear this out, and point as well to a sex ratio considerably favoring the marriage and remarriage chances of males. These imbalances can be seen in Table I I. Taking all

Table 11 Marital Status by Age and Sex, Blacks, I880

\begin{tabular}{|c|c|c|c|c|c|c|}
\hline & \multicolumn{2}{|c|}{ MARRIED } & \multicolumn{2}{|c|}{ ALL UNMARRIED } & \multicolumn{2}{|c|}{ WIDOWED ONLY } \\
\hline & MALES & FEMALES & MALES & FEMALES & MALES & FEMALES \\
\hline $15-19$ & I3 & I43 & 925 & I,434 & I & 9 \\
\hline $20-24$ & 426 & 986 & $\mathrm{I}, \mathrm{I} 47$ & $\mathrm{I}, 574$ & 8 & 79 \\
\hline $25-29$ & 929 & I,206 & 806 & 947 & 44 & 158 \\
\hline $30-34$ & 939 & 937 & 464 & 577 & $4 \mathrm{I}$ & 207 \\
\hline $35-39$ & 970 & 839 & 333 & 549 & 52 & 288 \\
\hline $40-44$ & $64 I$ & $5 \div 3$ & $2 I I$ & 486 & 62 & 293 \\
\hline $45-49$ & 425 & 325 & I 24 & 397 & 47 & 285 \\
\hline $50-54$ & 376 & 257 & II 4 & 453 & 48 & 338 \\
\hline $55-59$ & I96 & I 44 & 78 & $25 I$ & 45 & 207 \\
\hline $60-64$ & I 84 & 74 & 70 & 275 & 43 & 229 \\
\hline $65-69$ & IOI & 45 & 36 & I74 & 27 & I 47 \\
\hline $70+$ & I I4 & 43 & 9I & 397 & 70 & 340 \\
\hline TOTAL & $5,3 \mathrm{I} 4$ & 5,512 & 4,399 & 7,514 & 488 & 2,580 \\
\hline
\end{tabular}

blacks in Philadelphia as our base, and not just those living in families with children (for the former constitute the marriage pool), we find that by ages $35-39$, more than one-fifth of all black women were living as widows. Overall in this age group, four in ten black women were, for one reason or another, not currently married; this is so for only a quarter of the men. ${ }^{19}$ Black women generally married men older than themselves by an average of about three years; therefore, we should treat the next older age category as the most likely remarriage pool for widowed black women. By this reasoning, 35-39 year-old widows

I9 This argument rests on the fact that the effective marriage pool for blacks was other blacks. See Theodore Hershberg, "Mulattoes and Blacks: Intra-Group Color Differences and Social Stratification in Nineteenth-Century Philadelphia," Journal of American History (forthcoming, 1976). 
looked to remarry 40-44 year-old men. This group, however, was smaller to begin with because of differential inmigration by sex. Because they were older, because males generally suffer higher mortality, and because of the physically taxing nature of "nigger work," the pool experienced still further attrition. Very nearly half of Philadelphia's large number of widows, then, can be "explained" by their inability to find suitably aged mates.

Aggravating the situation even more is the fact that black males may have had more reason to leave the city than females when their spouses died, or to have placed their children with friends or relatives, rather than raise them alone on a scant and uncertain income. Women more easily than men could find jobs and at the same time support their children. (It is also possible that Philadelphia attracted an inmigration of widowed women. A detailed analysis of the widowed black population of Philadelphia, however, indicates that unlike native whites, black inmigrants who were widowed were, if anything, less likely at given ages than those born in Pennsylvania to be household heads, and among those who were household heads, less likely to have children.) Many of the female heads of families were employed as seamstresses and domestics, or were able to take in boarders, thus making it possible for them not to remarry. Unless female kin were available to serve as parent surrogates, men undoubtedly found it more difficult to remain unmarried, especially with young children. Finally, men had a further advantage in the remarriage market because they could more actively initiate a marriage contract. Women without means commanded little bargaining power and therefore were in an especially weak position to attract a mate.

We have chosen to accept as prima facie evidence the marital status recorded by census marshals a hundred years ago. We have not done so naively. We recognize the likelihood that at least some black female respondents may have told the census marshals what they thought they wanted to hear, explaining by "widowhood" the absence of a male household head, whatever the real reason. ${ }^{20}$ But we can validate the

20 We would expect that among female heads with children, the proportion of widows would increase with the age of the youngest child of the female head, since (assuming no illegitimacy) the younger the child, the fewer the elapsed years since the female head's husband surely was alive. Trends along these lines are present but quite weak and irregular; they are, however, virtually identical for each of the four ethnic groups. If we have not in this fashion gained greater confidence in the literal meaning of census "widowhood," we have discovered that its meaning seems to have been similar across ethnic lines. 
plausibility of the claims of widowhood by reference to death statistics contained in other documents and to known patterns of mortality by age. Our procedure has been to construct estimates of joint survival probabilities for a hypothetical population of black couples, which will allow us to suggest, at appropriate levels of mortality, the likely, or "expected" proportion of widows among the once-married female population, assuming for the moment that remarriage is negligible. ${ }^{2 I}$ Table I 2 compares the "expected" proportions of widows at this level of mortality with that measured for the whole black female population of Philadelphia in I880; we have also prepared a slightly more severe mortality schedule displayed in the same Table.

The findings are unequivocal. By far the greatest part of reported "widowhood" can readily be explained by the level of mortality among black Philadelphians. To be sure, there was some remarriage of widows, which would suggest a somewhat greater discrepancy between stated "widows" and the proportion expected by mortality alone. Table I 2 shows a close fit at all ages between expected and observed widowhood, suggesting that a fraction of declared widows were not so, but rather were unmarried or deserted women hiding their actual condition from the census taker.

2I Mortality for "colored" persons (including negligible numbers of Chinese, Japanese, and Indians) for Philadelphia in 1890 and for the six years preceding 1890 are derived from registration materials tabulated in U.S. Census Office, Eleventh Census, 1890 (Washington, I895), IV: Mortality, 662, 1046-1047. John S. Billings, who supervised the I 890 vital statistics volumes, noted that, as in the other 27 cities to which he devoted a volume, registration of deaths was "based upon certificates of deaths by physicians, [collected] under a compulsory registration law." The crude colored death rate in Philadelphia, 30.I, can be compared with the rate there for whites, 23.0, and with colored death rates of 32.9 in Baltimore, 34.0 in Washington, 34.6 in New York, and 30.9 for all 28 cities studied (U.S. Census Office, Report on Vital and Social Statistics of the United States at the Eleventh Census: 1890, Part II-Vital Statistics. Cities of 100,000 Population and Upward [Washington, I892], I-5). The age-specific figures, distributing the unknown ages, and taking the average one-year level from the figures for the sixyear period, were then compared with linearly interpolated estimates for I887 of the Philadelphia black population by age and sex, based on PSHP grid-square tallies for $\mathrm{I} 880$ and U.S. Census Office, Population, 1890, II, I27. The age-specific mortality rates were matched with model life tables in Ansley J. Coale and Paul Demeny, Regional Model Life Tables and Stable Populations (Princeton, 1966), and a good match was found on ages 20-50 at South Level 3, a severe mortality regime where the high rate of infant and child mortality proved closer to the observed Philadelphia black mortality than did the West series tables, more often applied to American populations. Good matches were also found between South Level 3 and the black life tables centering on 1879 for Baltimore and Washington, cited above, note 15 . South Level 3 implies an expectation of life at birth of 25 years; Level 2 implies 22.5 years. 
\begin{tabular}{l|l} 
THE URBAN BLACK FAMILY & 23I
\end{tabular}

Table 12 "Expected" Proportion of Widows Among EverMarried Black Women, I887, at Two Levels of Mortality, Compared with Proportion Recorded in the 1880 Census, by $\mathrm{Age}^{\mathrm{a}}$

\begin{tabular}{cccc}
\hline AGE & “EXPECTED”AT & “EXPECTED” AT & "MEASURED," \\
& $\begin{array}{c}\text { SOUTH LEVEL } 3 \\
\text { MORTALITY }\end{array}$ & $\begin{array}{c}\text { SOUTH LEVEL 2 } \\
\text { MORTALITY }\end{array}$ & I880 CENSUS \\
$25-29$ & 7.2 & I4.8 & I I.5 \\
$30-34$ & I4.I & 2 I.6 & I 8.I \\
$35-39$ & 21.3 & 28.7 & 25.4 \\
$40-44$ & 29.1 & 36.5 & 36.1 \\
$45-49$ & 37.5 & 45.6 & 46.6 \\
$50-54$ & 47.0 & 53.4 & 56.5 \\
$55-59$ & 57.8 & 63.5 & 59.0 \\
$60-64$ & 69.9 & 74.6 & 75.3 \\
$65-69$ & 81.8 & 84.3 & 76.2 \\
\hline
\end{tabular}

a Figures shown are percentages.

VARIANT PATTERNS IN FAMILY COMPOSITION In bringing out the excess of widowed female heads among blacks, the data presented in Table Io also reveal a persistent difference in headship by "other females," most of whom are married without spouse (Table 9). The proportion of "other female" headship for blacks is about 5 or 6 percent, unvarying with age. We have here what might be considered a variant pattern.

In our attempt to probe the source of this variant pattern, we examined marital status by age of non-widowed female heads. Divorcées at every age represent an insignificant proportion of this group. Unmarried mothers, although constituting almost a quarter of all female heads less than 30 , virtually disappear at older ages. Separated women are at every age the largest proportion of non-widowed female heads, but their numbers, too, decline with age. This decline cannot be explained by mortality alone. These patterns are identical across ethnic groups.

Had there been cultural support within the black community for female-headed families (whatever the reason), we should have found a growing number of families of this type with advancing age. Instead, they decline, doing so in the face of a remarriage market that offered them extremely limited prospects. In summary, the data provide no evidence for believing that Philadelphia's blacks valued anything 
distinct from what poverty and death often denied them: to raise their children in stable and continuous families.

Much of the speculation about the origins of the matrifocal black family has been uninformed by systematic historical data. In recent years, historians have begun to correct this situation. It is becoming increasingly clear with each new study that misconceptions about the past have resulted in certain erroneous interpretations of the present. The PSHP data indicate that the household structure in I850, I870, and I 880 was highly similar among each of the ethnic groups. Black families were just as likely to be organized in nuclear households, and, hence, were not more or less able to adapt to conditions created by industrialization than other ethnic groups. A somewhat higher proportion of black families were headed by a female than was true for other ethnic groups. However, we argue that a cultural explanation cannot account for this disparity.

In the first place, the great majority of black families were coupleheaded. Second, ex-slaves were more likely to reside in couple-headed households. Third, when property holding among the different ethnic grouping was held constant, variations in family composition largely disappeared. Finally, we were able to show that economic status had a powerful effect on the structure of the black family because blacks suffered extremely high mortality and females with children faced difficulties in remarrying. To the extent that the female-headed family appeared during this period, it emerged, not as a legacy of slavery, but as a result of the destructive conditions of northern urban life. ${ }^{22}$

With a few important exceptions, students of black history have not adequately appreciated the impact of the urban experience. In part, this is because the institution of slavery has so dominated the history of Afro-Americans. Ever since the I920s when justification for the low status of black Americans shifted from a genetic to an environmental interpretation, scholars have for the most part accepted without question

22 This interpretation finds support in the statistics offered by Gutman, "Persistent Myths,"above.Of all of the urban and rural communities that he studied, those with the highest percentages of female-headed households were cities: Natchez $(30 \%)$, Beaufort $(30 \%)$, Richmond $(27 \%)$, and Mobile $(26 \%)$, although the percentages for rural areas were all below $19 \%$. These percentages, moreover, if re-calculated after childless households are removed (see note 9 above), may increase as much as 8 percentage points. The cities varied widely in their size, type of economy, and rate of growth, to be sure; nonetheless, some differential process must have been operating to generate these statistics. 
the slavery hypothesis. After all, it followed logically that any institution as morally reprehensible as slavery also had to be destructive.

We do not wish to imply that the institution of slavery was not brutalizing and dehumanizing. Yet, one must not convert a sense of moral outrage into a monolithic interpretation of the black experience. Once we recognize that the matrifocal black family is a product of economic discrimination, poverty, and disease we cease to blame the distant past for problems which have their origins in more recent times. It was, and still is, much easier to lament the sins of one's forefathers than to confront the injustices of more contemporary socioeconomic systems. 